Berkeley with the active co-operation of the Seismological Station at that institution (Prof. Perry Byerly). Two required visible readings but a third automatically recorded pictures of the interferometer fringes every hour. No outstanding tilts could be associated with local earthquake activity. From October 1938 until January 1939 a triangulation resurvey was made of certain monuments in the locality between Petaluma and Point Reyes, California, originally established in 1928; about fifty stations were occupied. It is intended that periodic re-observations of this scheme will be made so that knowledge of possible earth movements may be obtained.

No tidal disturbances of seismic origin were noted on the gauges of the Bureau and co-operating stations cluring the year. One earthquake was reported felt by a vessel of the Coast and Geodetic Survey. This was on August 19 at Dutch Harbour, Alaska. Those aboard the ship felt four or five jolts.

\section{ENTRY OF YOUTH INTO INDUSTRY}

T

HE importance attached to the welfare of youth was reflected in the recent debate in the House of Commons on the Education Estimates; few of the many aspects of reconstruction problems after the War are more vital than that concerned with the welfare of youth. The memorandum on the problems of post-war entry of juveniles into employment, prepared by the London Regional Advisory Council for Juvenile Employment and recently submitted to the Ministry of Labour and National Service, emphasizes a vital aspect of juvenile welfare to which Political and Economic Planning directed attention in an admirable report, "The Entrance to Industry", so long ago as 1935. The memorandum adds little to what is contained in that report, but its arguments are ably reiterated. They are still valid, for while some progress has been made in regard to the provision of the social services required, we have scarcely begun to implement the long-term programme envisaged in the P E P report. Any charter of youth that may be promulgated will fail of its purpose if it does not receive the fullest consideration of all that is implied in the vital question of entry into employment. The plea of the London Regional Advisory Council that the economic aspect of the life of youth should not be neglected in the midst of educational, social, athletic or other preoccupations is indeed opportune.

Recalling the recommendation of the Malcolm Committee that education, whatever form it takes, should be related to the needs and eircumstances of lif $\theta$, which for a vast majority of boys and girls means life spent in industry or commerce, the memorandum suggests that training for life implies a preparation for citizenship in the broadest sense, and that such training should be an integral part of the life of the school and of the curriculum in extension of work done in earlier services, the whole method and practice being linked with material services, such as fine school buildings, physical and recreative work, music, free meals, and also with the other social services. There should be an attempt in the last period of this portion of school life to ease the transition from school to the larger world outside through the creation of a club atmosphere, accompanied by corresponding modification of the curriculum.
While occupational guidance might be given in the schools by specially qualified teachers, no attempt should be made at direct training for livelihood except in schools directly concerned with technical training. In regard to part-time schools, the memorandum emphasizes that the main function is to continue the general education of the pupils, particularly in the broad aspects of citizenship; also that if the day continuation system is to be well and truly established, it must receive the wholehearted support of employers. It is to be hoped that the social conscience will finally reject the notion that if the young worker wants continuative education, it is his own business to seek it in the evening after a full day's work.

The particular difficulty which the small employer and small working unit present in this respect is recognized, as are those inherent in reconciling the claims of industry and education. The Council suggests that the position of the young person in industry should be regarded from the broad point of view of entry into employment, conceived as a continuous process moving by degrees from school life, through the sphere of youthful work, into the wider world of adult labour. It suggests the extension of the school medical service for the physical wellbeing of all minors, or at least medical examination so as to ensure that all juveniles are physically suited to enter the employment of their choice. Welfare work in industry should be closely related to the true needs of young workers; and to correct the excessive tendency to enter clerical occupations rather than trades the memorandum advocates the establishment of vocational training schemes based on expert sifting and guidance and the closest liaison with those responsible for apprenticeship.

The memorandum touches on a number of points in war-time experience such as the Essential Work Order, which may contain elements of permanent value for juveniles, and it directs special attention to three sections of the field common to education and industry of which little is heard: the need for a new outlook on the whole question of apprenticeship; the need for greater mobility of labour to meet unexpected changes in economic organization and location of industry; and the need for ensuring that those who have entered employment as 'learners', in the widest sense of the term, shall be equipped with that degree of adaptability which will enable them to meet the demand of any sudden turnover to new materials or fundamental revision of technique, as, for example, the changes which are bound to come as a result of the ever-increasing use of synthetic materials. These are questions of increasing significance, and it is essential that education and industry should work closely together in this field if the problems arising from them are to be solved. While deprecating pressure for too rapid development after the War, the Council would welcome and support any scheme calculated to secure the growth of a sympathetic understanding by teachers and educational administrators of the needs and problems of business and industry, and it is urged that such mutual relations should be fostered and encouraged.

The problem of youth in industry is essentially a question of entry into employment. The employer must consider the position of his young employees as an integral element in his management and organization. This will require the elosest liaison and fullest co-operation between associations of employers and the trade unions to raise the entry 
into employment of juveniles to the status of industrial relationship. At the same time, education authorities must face the realities of the economic world which the juvenile will enter or has recently entered. The day continuation school may become a real meeting-ground between the two worlds of education and industry if it is administered, not merely as an educational service, but also as a means of recovery and refreshment for the young worker. Until, however, the problem of entry into employment is tackled by all concerned as part of industry as a whole, all elaborations of the machinery of choice of employment and vocational guidance will be vain and its products largely a matter of hazard.

\section{HOUSEHOLD LIGHTING, HEATING AND VENTILATION}

PA APERS read at two of the series of twelve meetings of the Royal Society of Arts recently devoted to "The Post-War Home : Its Interior and Exterior", have now been published (J. Roy. Soc. Arts, June 26). R. Fitzmaurice, principal scientific officer at the Building Research Station of the Department of Scientific and Industrial Research, gave a lecture on the lighting, heating and ventilation of the ordinary house. Many facts of topical interest relating to domestic use of fuel and power were included. Nonfunctional design of working kitchens leads to needless waste of lighting. Plans are reproduced of the distribution of daylight in ill- and in well-designed kitchens using the same ground-plan with redistribution of the same areas of glass in the walls.

All three subjects are intimately related. Large window areas or windows opened for ventilation may lead to excessive use of fuel for heating. It is estimated that about half the total quantity of coal raised in Great Britain is used for providing warmth in buildings, the remaining half being used for power and heat in industry. Although Germany has a colder winter and maintains better heating conditions in buildings, the consumption of coal for heating per head of the population is considerably less than in Great Britain. Less use of open fires and increased use of smokeless fuel help economy. From a graph reproduced it is shown that in the last forty years the price of coal in London has more than doubled.

The very variable nature of the British climate is an obstacle to the use of some highly efficient heating systems. For example, in the United States, Germany and the U.S.S.R. centralized heating of a whole district from a single boiler house is practicable. It is well known that large plants need to work as nearly as possible to their capacity to obtain a high order of running efficiency. In Great Britain, however, an installation capable of handling the heating load during our relatively limited cold weather would not be running nearly to its capacity over the greater part of the heating season.

Contributions to the discussion included one by R. Grierson, of the Northmet Power Company, who gave details for the small house. The lowest amount spent per year for heating services-coke, coal, gas and electricity-is about £7-£8 a year. The ordinary clerk or member of the lower-paid professional classes spends $£ 15-£ 20$ per year. Mr. Grierson gave full details for his own house, where
$£ 28-£ 30$ a year is spent in heating its 12,000 cubic feet of space. For windows, a glass area of about 20 per cent of the floor area under normal conditions gives adequate natural lighting. A ratio of $12 \frac{1}{2}$ per cent makes a room definitely too dull.

The common type of German stove "is not a thing of beauty, but it does make for efficiency (45-70 per cent) and reduces the amount of heat energy lost up the chimney. If the Englishman gets 20 per cent of the heat energy of the coal into the room, that is to say, if he gets $12 s$. worth of heat out of $£ 3$ worth of coal, he is fortunate". In view of the national requirements in the economical use of fuel, these figures give food for thought.

A serious difficulty lies in the fact that the initial expense of the more efficient heating devices in a home is always greater than that of the inefficient. Similarly, a further wastage occurs in cheap roofing of houses. After the War of 1914-18, many cheap houses were built with roofs of tiles on laths. No lining of felt or other material under the tiles was used. As a result, the wind blows right through the loft space, the water in the cold storage tank is frozen in the cold weather, and the bedrooms are separated from an atmosphere which during last winter fell in temperature to $14^{\circ} \mathrm{F}$., by about three quarters of an inch of lath and plaster ceiling. Such roomssimilar conditions also occur in living-rooms in cheap bungalows-are in effect fitted with panelcooling; for it is found that on a hot day, if the temperature of the ceiling is only $10^{\circ} \mathrm{F}$. below that of the room, the cooling effect is most marked.

Mr. A. F. Dufton, also from the Building Research Station, found that a gas fire, designed to burn $0 \cdot 2$ therm an hour ( $5-8 \mathrm{kw}$.), had to be used for two hours in all in order to warm a room for half an hour for breakfast, so long as the walls remained in their original condition, consisting of plaster and wallpaper. When, however, the heat absorption of the walls was reduced by lining them with wood panelling, half an hour of previous heating instead of the original one and a half hours sufficed.

The eleventh lecture in the series was given by Miss Helen Masters, who dealt with equipment and maintenance in the kitchen. While the heat requirements for cooking are here again of great importance, many other factors are involved. The mere accumulation of labour-saving devices, without organization of the work to be done, will not promote efficieney. Architects have sometimes given so much attention to reducing the number of steps to be taken in walking from one part of the kitchen to another that they have designed kitchens which are too small to work in at all.

\section{SOUTH-EASTERN UNION OF SCIENTIFIC SOCIETIES}

\section{ANNUAL CONGRESS}

7 HE South-Eastern Union of Scientific Societies held its forty-seventh annual congress at Guildford on July 25, a single day of sessions and excursions attended by seventy representatives and members.

A representative assembly to transact the business of the seventy constituent societies was held in the County School for Girls, at which Dr. J. Ramsbottom, 